\title{
RADICAL-TYPE REACTIONS IN PROTIC AND APROTIC MEDIA: COMPARISONS IN NICKEL-CATALYSED ELECTROCHEMICAL REDUCTIVE CYCLISATIONS
}

\section{REACTIONS RADICALAIRES DANS DES MILIEUX PROTIQUES ET APROTIQUES : COMPARAISONS ENTRE LES CYCLISATIONS REDUCTIVES ELECTROCHIMIQUES CATAL YSEES PAR DES COMPLEXES DU NICKEL}

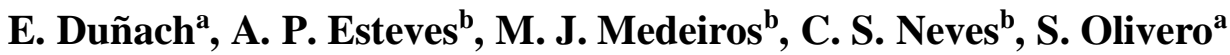 \\ ${ }^{a}$ Laboratoire de Chimie des Molécules Bioactives et des Arômes, CNRS, UMR 6001, Institut de \\ Chimie de Nice, Université de Nice-Sophia Antipolis, Faculté des Sciences, Parc Valrose, 06108 \\ Nice Cedex 2, France \\ dunach@unice.fr \\ ${ }^{b}$ Centro de Química, Universidade do Minho, Largo do Paço, 4704-553 Braga, \\ Portugal
}

\begin{abstract}
The electrochemical reductive cyclisation of unsaturated organic halides in the presence of $\mathrm{Ni}$ (II) complexes as the catalysts was examined in aprotic solvents such as DMF and in protic solvents such as ethanol, butanol or ethanol-water mixtures. The presence of the alcohol media enhanced the rate of recycling of the catalytic species.
\end{abstract}

Résumé: La cyclisation réductive électrochimique d'halogénures insaturés en présence de complexes de $\mathrm{Ni}(\mathrm{II})$ comme catalyseurs a été examinée dans des solvants comme le DMF et dans des solvants protiques comme l'éthanol, le butanol ou des mélanges éthanol-eau. La présence du milieu alcoolique augmente la vitesse du recyclage des espèces catalytiques.

In terms of development of environmentally more friendly synthetic organic processes, the search for alternative methodologies such as electrochemical synthesis constitute interesting targets. As compared to conventional oxidative and reductive processes in organic chemistry, in which the classical chemical oxidants and reductants are often used in stoichiometric amounts, the synthesis via electrochemical methods uses the electrons as clean, mild, selective, cheap and environmentally friendly reagents.[1]

We have been interested in the development of reductive intramolecular cyclisations using electrochemical methods. Whereas non-reductive cyclisations of unsaturated halides have been widely reported using organometallic catalysis, $[2,3,4]$ conventional reductive cyclisations require the use of stoichiometric amounts of metallic reductants, such as, for example, diiodo samarium[5,6] or tin hydrides (Scheme 1).[7,8]

\section{Here Scheme 1}

We have been working with $\mathrm{Ni}(\mathrm{II})$ complexes as catalyst precursors in view of the electrochemical in situ generation of $\mathrm{Ni}(\mathrm{I})$ species. [9] In particular, $\mathrm{Ni}$ (II) macrocyclic complexes 
have been reported to generate single-electron reduced $\mathrm{Ni}(\mathrm{I})$ species, which can further catalyse the reductive radical cyclisation of unsaturated organic halides, [10,11,12] $\alpha$-bromoacetals bearing olefinic moieties [13] and 2-haloaryl ethers containing unsaturated side chains.[14] In these electrochemical cyclisations the solvent used is an aprotic and polar solvent, generally DMF. However, DMF may present some toxicity as the solvent.[15,16] The possibility to effect reductive cyclisations in protic media has been recently reported.[17] Within a perspective aimed at cleaner and catalytic syntheses, we report here some comparative electrosyntheses run either in DMF or in ethanol and ethanol-water mixtures as the solvents for selected Ni-catalysed electroreductive intramolecular cyclisations. The comparative behavior in aprotic and protic solvents of these systems examined by cyclic voltammetry is also discussed.

We studied the compared reactivity of three different unsaturated organic bromides: the 3propargyloxy $\alpha$-bromoester, 1, the 3-allyloxy $\alpha$-bromoester, 2 , and the 2-bromoaryl olefinic derivative, $\mathbf{3}$ (see equations 1-3). The cyclisations of 1-3 were carried out under catalytic and mild conditions, at room temperature. Two stable and easily available $\mathrm{Ni}^{\mathrm{II}}$ catalyst precursors, $\mathrm{Ni}\left(\right.$ cyclam) $\mathrm{Br}_{2}$, (cyclam $=1,4,8,11$-tetraazacyclotetradecane) and $\mathrm{Ni}(\mathrm{tmc}) \mathrm{Br}_{2},(\operatorname{tmc}=1,4,8,11$ tetramethyl-1,4,8,11-tetraazacyclotetradecane) [18] were used in $20 \mathrm{~mol} \%$ for the cyclisations (Figure 1).

\section{Here Figure 1}

These two $\mathrm{Ni}^{\mathrm{II}}$ complexes, which generate $\mathrm{Ni}(\mathrm{I})$ intermediates after a one-electron reduction,[19] have been shown to be efficient in reductive processes involving aryl halides.[14,20]

The cyclisations of 1-3 were run on a preparative-scale using a single-compartment cell fitted with a carbon fiber cathode and a consumable metal anode, generally a magnesium rod, and were carried out in different solvents at a constant current intensity of $30 \mathrm{~mA}\left(j=0.15 \mathrm{~A} \mathrm{dm}^{-2}\right)$. The complete consumption of the substrates required 2-4 $\mathrm{F} \mathrm{mol}^{-1}$.

The electroreduction of $\mathbf{1}$ (eq. 1) carried out in the presence of $\mathrm{Ni}\left(\right.$ cyclam) $\mathrm{Br}_{2}$ using $\mathrm{Mg}$ anode in DMF with $n-\mathrm{Bu}_{4} \mathrm{NBF}_{4}$ as the supporting electrolyte $(6 \mathrm{mM})$, led to an overall yield of $63 \%$ cyclisation as a mixture of furan derivatives $\mathbf{4}$ and $\mathbf{5}$ in a 48:52 ratio (Table 1, entry 1). No sixmembered pyran rings were formed and both $\mathbf{4}$ and $\mathbf{5}$ presented a trans-configuration, in agreement with the configuration of the starting material.

\section{Here Eq. 1}

During electrolysis, the cathodic reaction concerns the $\mathrm{Ni}^{\mathrm{II}}$ to $\mathrm{Ni}^{\mathrm{I}}$ reduction, which is followed by the insertion of $\mathrm{Ni}^{\mathrm{I}}$ to the $\mathrm{C}-\mathrm{Br}$ bond of $\mathbf{1}$ and further reaction on the triple bond. Additional reduction and protonation by the electrolytic medium affords the furan derivative $\mathbf{4}$ as the primary expected cyclisation product. The furan moiety is an important subunit in a wide range of biologically active natural products,[21] and the nickel-catalysed radical cyclisation has also been applied to the synthesis of several substituted tetrahydrofurans.[22,23,24] Dihydrofuran 5 is issued from the isomerisation of $\mathbf{4}$ to the more conjugated isomer. 
The same reaction of $\mathbf{1}$ with $\mathrm{Ni}\left(\right.$ cyclam) $\mathrm{Br}_{2}$ using a zinc anode led to a $78 \%$ of $\mathbf{4}$ (entry 2). Using $\mathrm{Ni}(\mathrm{tmc}) \mathrm{Br}_{2}$ with a zinc anode, the cyclisation of $\mathbf{1}$ led to $\mathbf{4}$ in $68 \%$ yield (entry 3 ).

Here Table 1

The reaction of $\mathbf{1}$ in $\mathrm{EtOH}$ was run in presence of $\mathrm{Ni}(\mathrm{tmc}) \mathrm{Br}_{2}$ and a $\mathrm{Zn}$ anode and afforded $\mathbf{4}$ and 5 in $83 \%$ yield and a 82:18 ratio (entry 4). It was interesting to note that the protic ethanol medium led to a more efficient cyclisation. The comparison of the cyclisation of $\mathbf{1}$ using a zinc anode in DMF and EtOH as the solvents (entries 3,4), indicates here again that the electrolysis in $\mathrm{EtOH}$ resulted in a higher yield than in DMF. When the same reaction was carried out with a $\mathrm{Mg}$ anode, the cyclisation yield was of $71 \%$ (entry 5). When the supporting electrolyte was changed from $\mathrm{Et}_{4} \mathrm{NBr}$ to $n-\mathrm{Bu}_{4} \mathrm{NBF}_{4}$ in $\mathrm{EtOH}$, the yield of 4 and 5 raises to $87 \%$ (entry 6). The cyclisation was also efficient in $n$-BuOH leading to $88 \%$ of $\mathbf{4}$ and $\mathbf{5}$ and a $63: 37$ relative ratio (entry 7 ). When 1 was reacted in EtOH: $\mathrm{H}_{2} \mathrm{O}(9: 1)$ as the solvent, the results were the best with an overall yield of $97 \%$ and a $\mathbf{4 : 5}$ relative ratio of $88: 12$ (Table 1 , entry 8 ). The change of the catalyst - substrate ratio from 20 to $10 \mathrm{~mol} \%$ led to similar results. This indicates that the ratio $[\mathrm{RBr}] /\left[\mathrm{Ni}^{\mathrm{II}}\right]$ doesn't interfere in reaction mechanism. Higher water ratio did not allow the complete solubility of the substrate.

The electrolyses of the allyloxy bromoester substrate 2 were also carried out with $\mathrm{Ni}(\operatorname{tmc}) \mathrm{Br}_{2}$ as the catalyst in DMF, EtOH and EtOH: $\mathrm{H}_{2} \mathrm{O}$ (9:1), as summarised in Table 2. In these cases, the cyclisation led selectively to a single five-membered ring tetrahydrofuran structure, 6 , as a mixture of two diastereoisomers (eq. 2).

Here Eq. 2

In DMF, the cyclisation yield was of $38 \%$. The efficiency of the reductive cyclisation was increased using EtOH as the solvent, reaching $61 \%$ of $\mathbf{6}$, with a relative isomeric ratio of 93:7. In EtOH: $\mathrm{H}_{2} \mathrm{O}$ (9:1), a 75\% yield was attained with the same isomeric ratio of 93:7.

Here Table 2

The role of EtOH as a protic solvent was also examined in the cyclisation of bromoaryl derivative 3. In this case, the comparison of the electroreductive cyclisations was done in DMF and in $\mathrm{EtOH}$, with $\mathrm{Ni}($ cyclam $) \mathrm{Br}_{2}$ as the catalyst and $n-\mathrm{Bu}_{4} \mathrm{NBF}_{4}$ as the supporting electrolyte, using a $\mathrm{Mg}$ anode (eq. 3).

Here Eq. 3 
The cyclisation of homoallyl ether $\mathbf{3}$ led to the indane structure $\mathbf{7}$ as the main reaction product (cis:trans), together with some dehalogenated compound 8. In DMF the yield of 7 was of 58\% with a cis:trans ratio of 40:60.[25] The results obtained in EtOH were here similar, with 55\% of cyclisation to 7 and a cis:trans ratio of 47:53, respectively. However, the amount of dehalogenation was lower in EtOH (15\% in EtOH versus 26\% in DMF).

The difference of efficiency of the cyclisations of $\mathbf{1}$ and $\mathbf{2}$ in protic and aprotic media may be explained by the mechanism of the electrochemical cyclisation.

The cyclic voltammogram of $\mathbf{1}$ in DMF, in the presence of $\mathrm{Ni}(\mathrm{tmc}) \mathrm{Br}_{2}$ is presented in Figure 2.

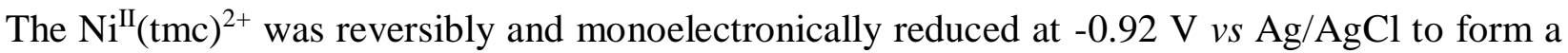
$\mathrm{Ni}^{\mathrm{I}}(\mathrm{tmc})^{+}$species. The addition of 1 equiv. of $\mathbf{1}$ to the DMF solution increased the reduction peak to a two-electron wave and the peak became irreversible. The cathodic peak increased its intensity up to a $\mathrm{Ni}^{\mathrm{iI}} / \mathbf{1}$ ratio of $1 / 5$, but upon addition of five or more equivalents of $\mathbf{1}$ versus $\mathrm{Ni}^{\mathrm{II}}$ (up to 10 equivalents) no further important increase was observed. The chemical bulk cyclisation reaction was therefore a slow reaction in terms of catalyst recycling. The data obtained from these experiments are presented in Table 3. It is to note that the substrate 1 itself was reduced beyond $-1.5 \mathrm{~V}$ in the absence of the $\mathrm{Ni}(\mathrm{II})$ complex.

\section{Here Figure 2}

In contrast, the cyclic voltammetry of $\mathbf{1}$ in the presence of $\mathrm{Ni}^{\mathrm{II}}(\mathrm{tmc})^{2+}$ in $\mathrm{EtOH}$, indicated that the progressive addition of the substrate to the reversible $\mathrm{Ni}^{\mathrm{II}} / \mathrm{Ni}^{\mathrm{I}}$ redox couple involved an important catalytic current at $-0.85 \mathrm{~V} v \mathrm{Ag} / \mathrm{AgCl}$, as shown in Figure 3.

\section{Here Figure 3}

The catalytic wave observed in Figure 3 is indicative of a faster chemical reaction, as compared to that in DMF, involving a more efficient recycling of the active catalytic species in the alcohol medium. The comparative data obtained from these experiments are summarised in Table 3 .

The cyclic voltammograms of $\mathbf{1}$ and $\mathrm{Ni}(\mathrm{tmc})^{2+}$ in EtOH: $\mathrm{H}_{2} \mathrm{O}$ (9:1) were similar than that observed in $\mathrm{EtOH}$.

Here Table 3

To explain the efficiency of the cyclisation in protic medium as compared to DMF, a catalytic cycle is presented in Scheme 2 for compound $\mathbf{1}$. 
The two first steps of $\mathrm{Ni}^{\mathrm{II}}$ to $\mathrm{Ni}^{\mathrm{I}}$ catalyst reduction and further oxidative addition to the $\mathrm{C}$ - $\mathrm{Br}$ bond of the substrate should be very similar in both media. The proposed organometallic $\mathrm{Ni}^{\mathrm{III}}$ species A undergoes cyclisation to form a vinyl-Ni ${ }^{\mathrm{III}}$ intermediaite $\mathbf{B}$ that is further reduced to $\mathbf{C}$ and protonated, thus liberating the organic product $\mathbf{4}$ and $\mathrm{Ni}^{\mathrm{II}}$. The most important difference in the mechanism upon solvent change should lie in the last reduction/protonation step. In DMF, the protonation is a slow process, due to the absence of protons in the medium. It has been reported in other related reactions, that the supporting electrolyte can be a source of protons affording tributylamine and butene in the case of decomposition of the tetrabutylammonium salts. [26] The DMF solvent can also act as a proton source in electrochemical reactions.[26] However, these protonation reactions should be slow processes.

\section{Here Scheme 2}

In the reactions run in protic media, the protonation of the $\mathrm{Ni}^{\mathrm{II}}$ intermediate $\mathbf{C}$ is highly facilitated and can take place efficiently. As a result, the $\mathrm{Ni}^{\mathrm{II}}$ catalyst is easily and rapidly recycled and accounts for the more intense catalytic wave observed in the cyclic voltammogram of Figure 3 as compared to Figure 2.

In conclusion, the radical-type cyclisations catalysed by $\mathrm{Ni}^{\mathrm{II}}$ macrocyclic complexes can be efficiently carried out in protic solvents with increased yield when compared to the same reactions carried out in DMF. The possibility to run organic electrochemical reactions in EtOH as the solvent medium is an interesting asset from the point of view of the use of environmentally more friendly reaction media. The use of electrochemical reductive methodologies instead of the more classical redox reagents also contributes to cleaner processes that can be run with high selectivities.

Acknowledgments: MJM would like to thank Fundação para a Ciência e Tecnologia (PPDCT/55576/2004) for the partial financial support of this work. 


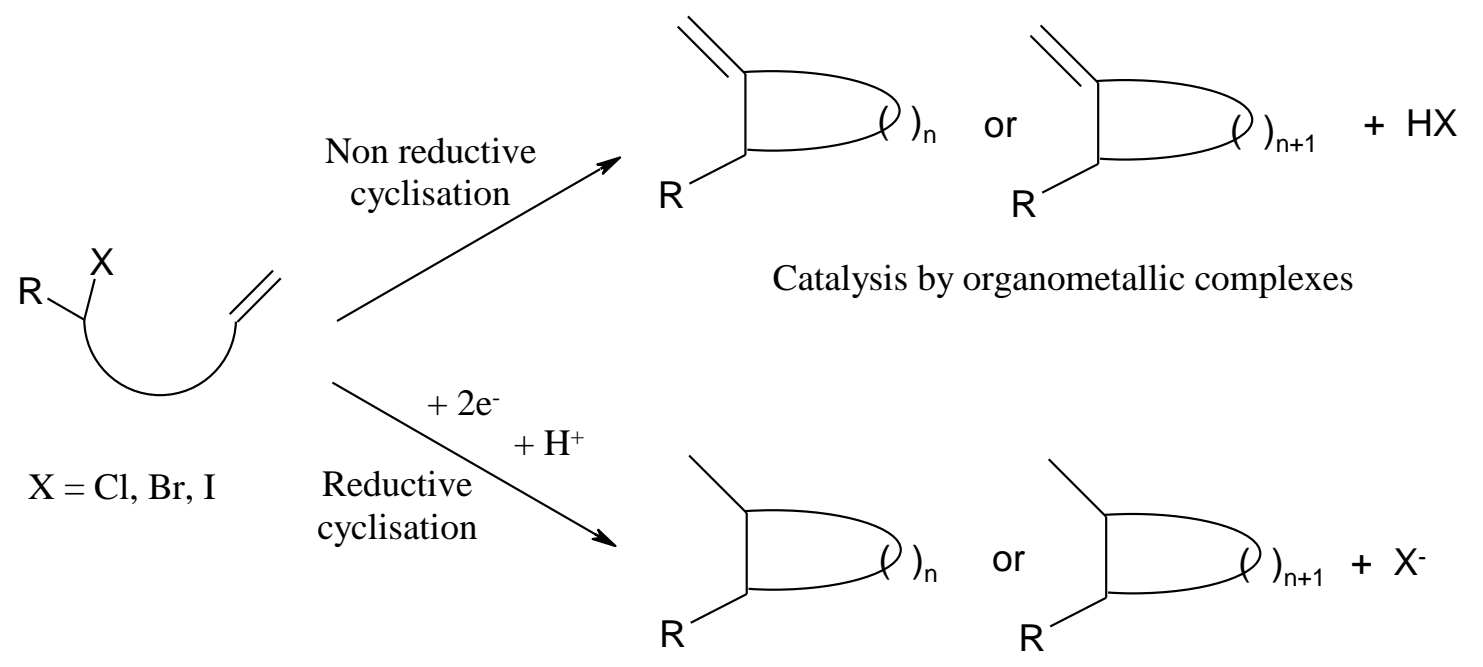

Stoichiometric cyclisations by conventional chemistry or catalytic cyclisation by electrosynthesis

\section{Scheme 1. Reductive intramolecular cyclisations.}

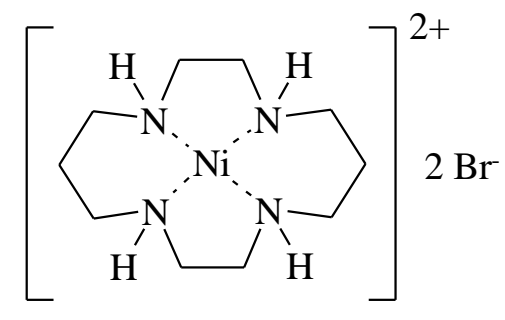

$\mathrm{Ni}($ cyclam $) \mathrm{Br}_{2}$

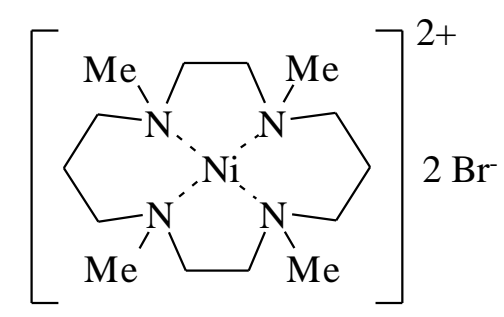

$\mathrm{Ni}(\mathrm{tmc}) \mathrm{Br}_{2}$

Figure 1

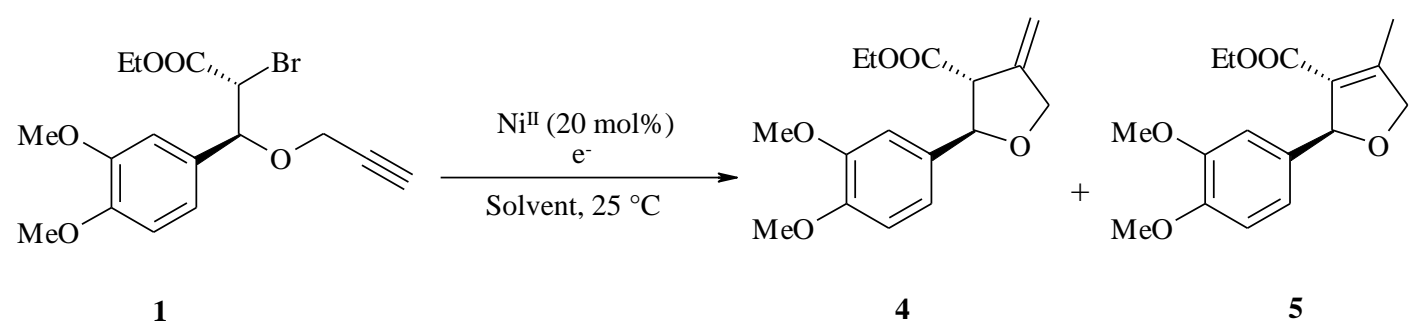

Eq.1 
Table 1. Intramolecular cyclisation of $\mathbf{1}(10 \mathrm{mM})$ catalysed by electrogenerated $\mathrm{Ni}^{\mathrm{I}}$ complexes (20 mol\%) in different solvents.

\begin{tabular}{|c|c|c|c|c|c|}
\hline Entry & Catalyst & $\begin{array}{c}\text { Solvent/ Supporting } \\
\text { electrolyte }\end{array}$ & Anode & $\begin{array}{c}\text { Cyclisation } \\
\text { products }(\mathbf{4 + 5})\end{array}$ & Ratio 4:5 \\
\hline 1 & $\mathrm{Ni}($ cyclam$) \mathrm{Br}_{2}$ & $\mathrm{DMF} / n-\mathrm{Bu}_{4} \mathrm{NBF}_{4}$ & $\mathrm{Mg}$ & $63 \%$ & $48: 52$ \\
\hline 2 & $\mathrm{Ni}($ cyclam$) \mathrm{Br}_{2}$ & $\mathrm{DMF} / n-\mathrm{Bu}_{4} \mathrm{NBF}_{4}$ & $\mathrm{Zn}$ & $78 \%$ & 100:- \\
\hline 3 & $\mathrm{Ni}(\mathrm{tmc}) \mathrm{Br}_{2}$ & $\mathrm{DMF} / n-\mathrm{Bu}_{4} \mathrm{NBF}_{4}$ & $\mathrm{Zn}$ & $68 \%$ & 100:- \\
\hline 4 & $\mathrm{Ni}(\mathrm{tmc}) \mathrm{Br}_{2}$ & $\mathrm{EtOH} / \mathrm{Et}_{4} \mathrm{NBr}$ & $\mathrm{Zn}$ & $83 \%$ & $82: 18$ \\
\hline 5 & $\mathrm{Ni}(\mathrm{tmc}) \mathrm{Br}_{2}$ & $\mathrm{EtOH} / \mathrm{Et}_{4} \mathrm{NBr}$ & $\mathrm{Mg}$ & $71 \%$ & $21: 79$ \\
\hline 6 & $\mathrm{Ni}(\mathrm{tmc}) \mathrm{Br}_{2}$ & $\mathrm{EtOH} / n-\mathrm{Bu}_{4} \mathrm{NBF}_{4}$ & $\mathrm{Mg}$ & $87 \%$ & $40: 60$ \\
\hline 7 & $\mathrm{Ni}(\mathrm{tmc}) \mathrm{Br}_{2}$ & $n-\mathrm{BuOH} / \mathrm{Et}_{4} \mathrm{NBr}$ & $\mathrm{Mg}$ & $88 \%$ & $63: 37$ \\
\hline 8 & $\mathrm{Ni}(\mathrm{tmc}) \mathrm{Br}_{2}$ & $\begin{array}{c}\mathrm{EtOH}: \mathrm{H}_{2} \mathrm{O}(9: 1) / \\
\mathrm{Et}_{4} \mathrm{NBr}\end{array}$ & $\mathrm{Mg}$ & $97 \%$ & $88: 12$ \\
\hline
\end{tabular}

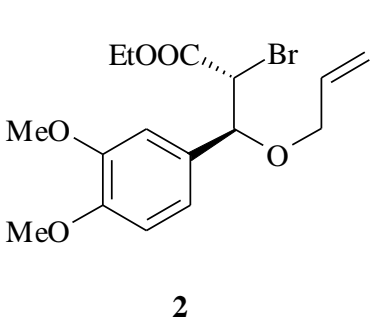

2

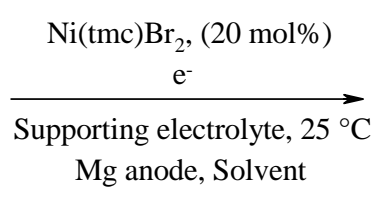

$\mathrm{Mg}$ anode, Solvent

Eq. 2

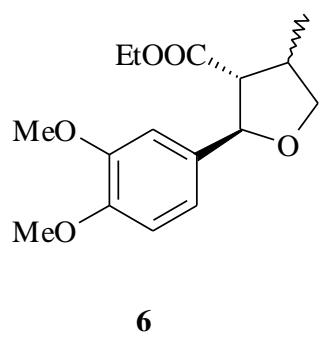

6 
Table 2. Intramolecular cyclisation of 2 catalysed by $\mathrm{Ni}(\mathrm{tmc}) \mathrm{Br}_{2}(20 \mathrm{~mol} \%)$ in different solvents.

\begin{tabular}{cccc}
\hline Entry & Solvent & $\begin{array}{c}\text { Supporting } \\
\text { electrolyte }\end{array}$ & \% of 6 (d.r.) \\
\hline 1 & DMF & $n-\mathrm{Bu}_{4} \mathrm{NBF}_{4}$ & $38(91: 9)$ \\
2 & $\mathrm{EtOH}$ & $\mathrm{Et}_{4} \mathrm{NBr}$ & $61(93: 7)$ \\
3 & $\mathrm{EtOH}: \mathrm{H}_{2} \mathrm{O}(9: 1)$ & $\mathrm{Et}_{4} \mathrm{NBr}$ & $75(93: 7)$ \\
\hline
\end{tabular}

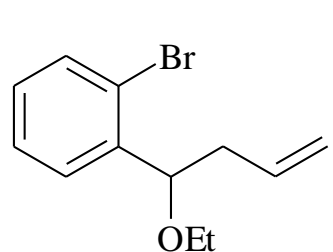

3

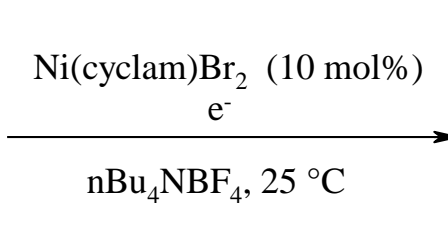

EtOH :

DMF :

Eq. 3

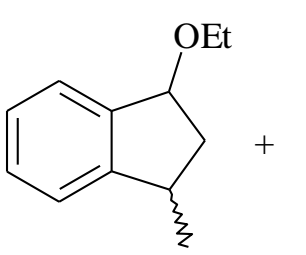<smiles>C=CCC(OCC)c1ccccc1</smiles>

7

$55 \%(47: 53)$

$58 \%(40: 60)$

8

$15 \%$

$26 \%$ 


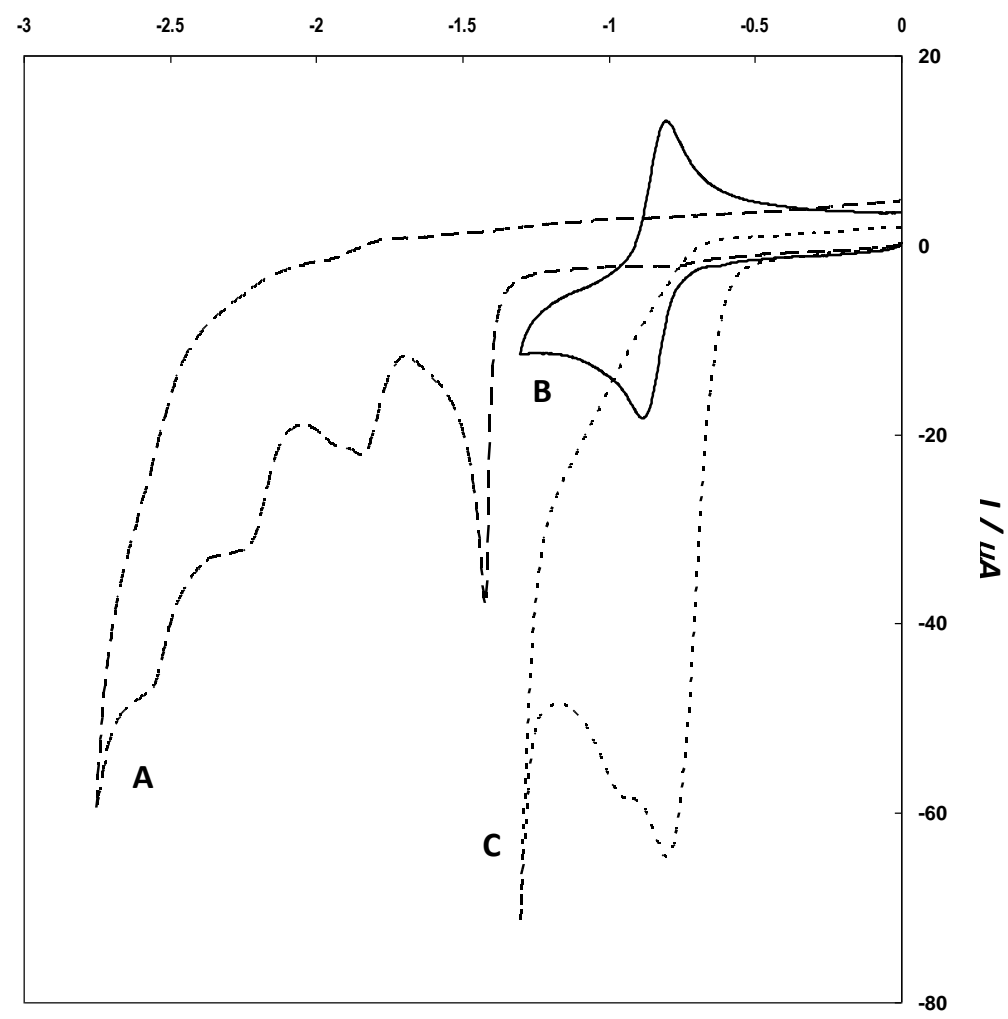

Figure 2. Cyclic voltammograms recorded with a glassy carbon electrode (area $\left.=0.077 \mathrm{~cm}^{2}\right)$ at $100 \mathrm{mV}$ $\mathrm{s}^{-1}$ in DMF containing $0.1 \mathrm{M} n-\mathrm{Bu}_{4} \mathrm{NBF}_{4}$ at room temperature: (A) $1.0 \mathrm{mM} \mathrm{1}$; (B) $1.0 \mathrm{mM}[\mathrm{Ni}(\mathrm{tmc})] \mathrm{Br}_{2}$; (C) $1.0 \mathrm{mM}\left[\mathrm{Ni}\left(\mathrm{tmc}_{\mathrm{m}}\right)\right] \mathrm{Br}_{2}$ and $5.0 \mathrm{mM} 1$. 
$E / V$ vs $A g / A g C l$

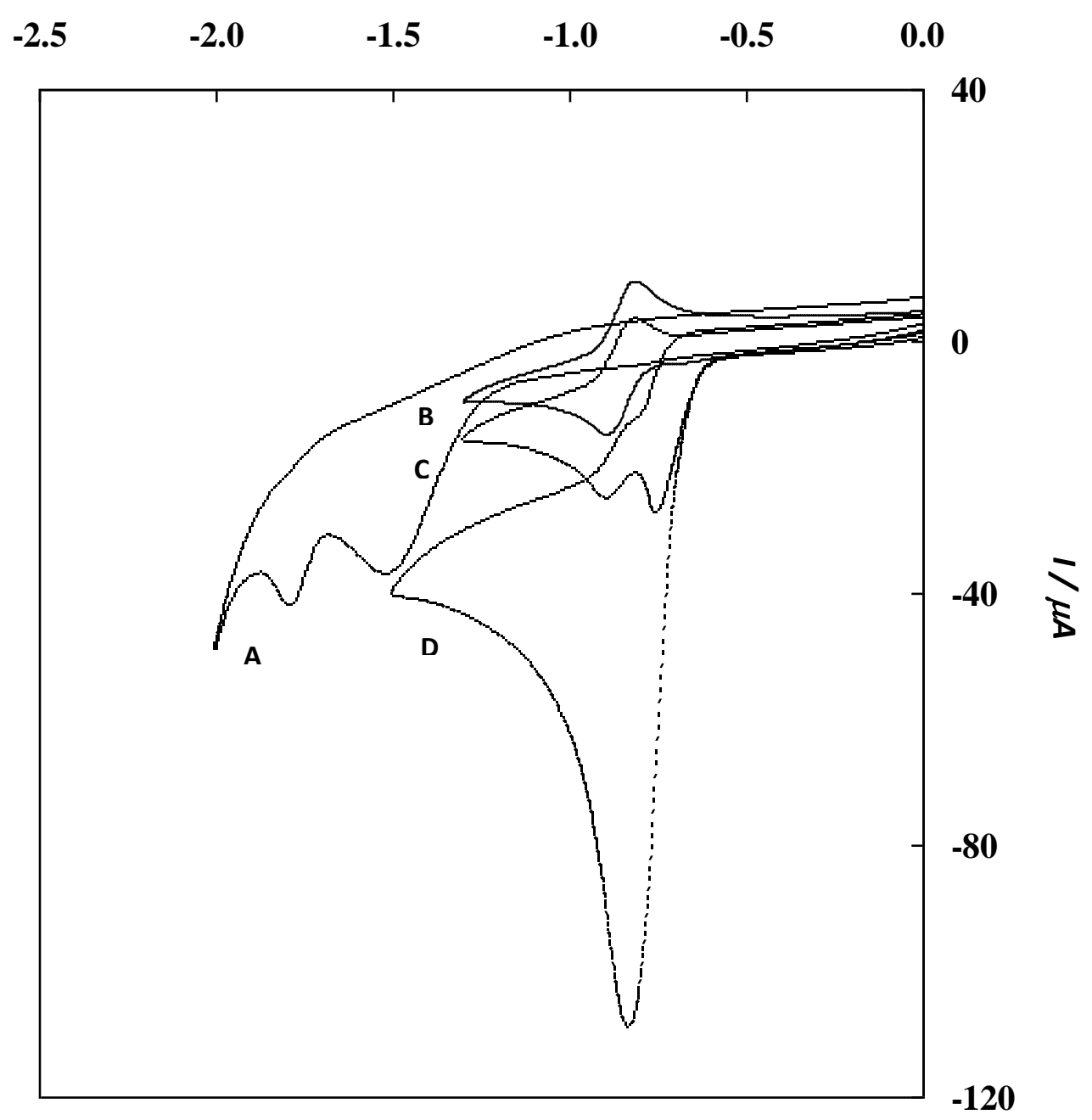

Figure 3. Cyclic voltammograms recorded with a glassy carbon electrode (area $\left.=0.07 \mathrm{~cm}^{2}\right)$ at $100 \mathrm{mV} \mathrm{s}^{-1}$ in EtOH containing $0.10 \mathrm{M} \mathrm{Et}_{4} \mathrm{NBr}$ at room temperature: (A) $2 \mathrm{mM} \mathrm{1;} \mathrm{(B)} 1 \mathrm{mM}$ [Ni(tmc)]Br ${ }_{2}$; (C) $1 \mathrm{mM}$ [Ni(tmc)]Br ${ }_{2}$ and $2 \mathrm{mM} \mathrm{1;} \mathrm{(D)} 1 \mathrm{mM}[\mathrm{Ni}(\mathrm{tmc})] \mathrm{Br}_{2}$ and $10 \mathrm{mM} 1$. 
Table 3. Peak-current ratios obtained from cyclic voltammograms of solutions containing $\mathrm{Ni}(\mathrm{tmc}) \mathrm{Br}_{2}(1.0 \mathrm{mM})$ and various concentrations of 1 at $100 \mathrm{mVs}^{-1}$.

\begin{tabular}{cccc}
\hline \multirow{2}{*}{ Solvent } & \multicolumn{3}{c}{$\mathrm{I}_{\mathrm{c}} \mathrm{I}_{\mathrm{p}}$} \\
\cline { 2 - 4 } & $\gamma=2$ & $\gamma=5$ & $\gamma=10$ \\
\hline DMF & 3.14 & 3.74 & 4.20 \\
EtOH & 2.20 & 5.10 & 9.80
\end{tabular}

Ic: catalytic peak current intensity of the catalyst in the presence of substrate and Id: peak intensity of the catalyst in the presence of substrate. $\gamma=$ $[1] /\left[\mathrm{Ni}\left(\mathrm{tmc}_{\mathrm{m}}\right) \mathrm{Br}_{2}\right]$

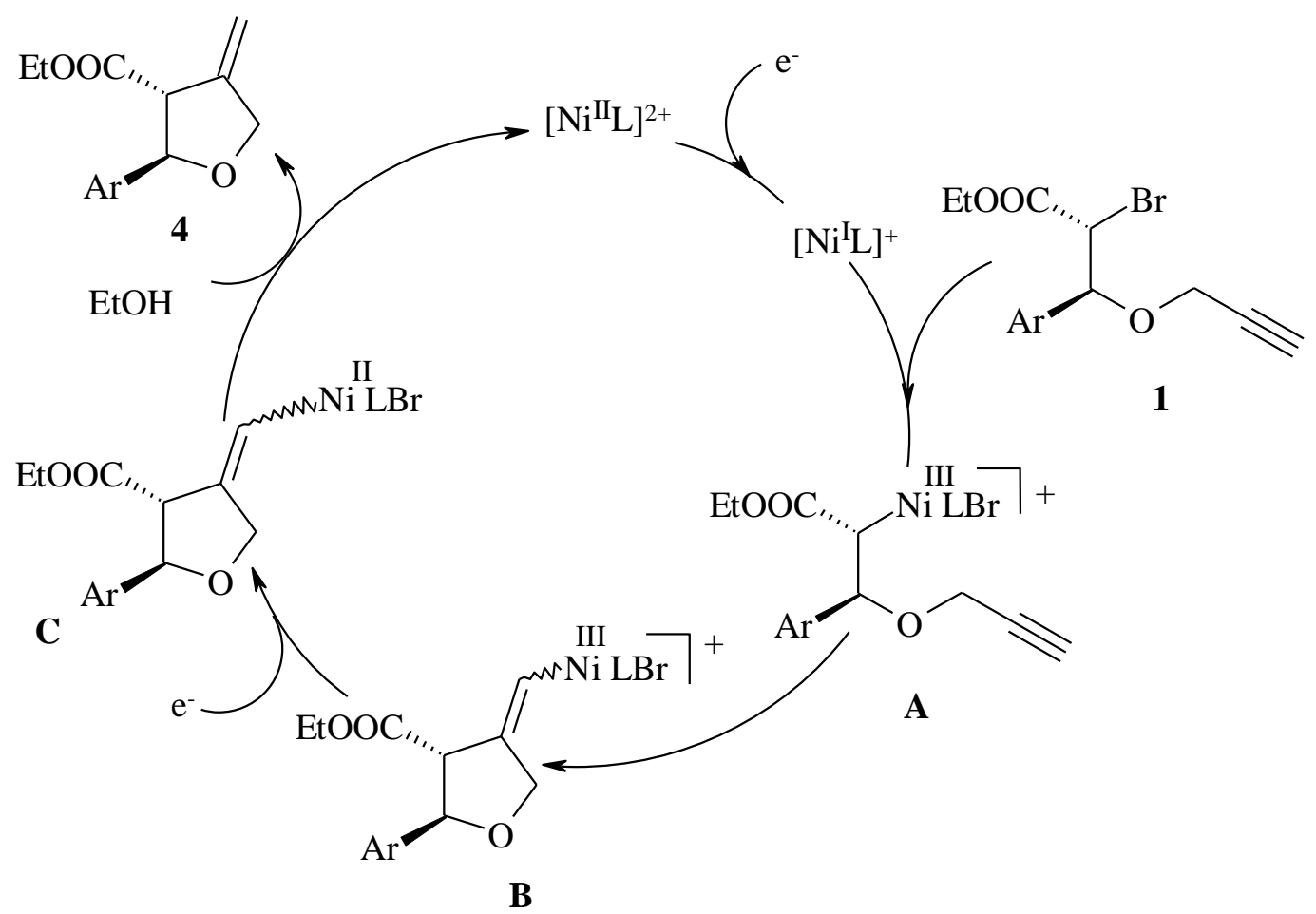

Scheme 2. 


\section{References}

[1] M. M. Baizer, H. Lund (2nd Ed.) Organic Electrochemistry: An Introduction and a Guide. Dekker, New York, N. Y. 1983.

[2] G. Zeni, R. C. Larock, Chem. Rev. 104 (2004) 2285.

[3] I. Nakamura, Y. Yamamoto, Chem. Rev. 104 (2004) 2127.

[4] C. Amatore, A. Jutand, Acc. Chem. Res. 33 (2000) 314.

[5] H. B. Kagan, Tetrahedron 59 (2003) 10351.

[6] G. A. Molander, C. R. Harris, Tetrahedron 54 (1998) 3321.

[7] M. Ihara, K. Yasui, N. Taniguchi, K. Fukumoto, J. Chem. Soc., Perkin Trans 1 (1990) 1469.

[8] D. P. Curran and J. Tamine, J. Org. Chem. 58 (1991) 2746.

[9] E. Duñach, M. J. Medeiros, S. Olivero, N. J. Chem. 30 (2006) 1534.

[10] S. Ozaki, E. Matsui, J. Waku, H. Ohmori, Tetrahedron Lett. 38 (1997) 2705 (and references cited therein).

[11] A. P. Esteves, A. M. Freitas, M. J. Medeiros, D. Pletcher, J. Electroanal. Chem. 499 (2001) 95.

[12] E. Duñach, A. P. Esteves, A. M. Freitas, M. J. Medeiros, S. Olivero, Tetrahedron Lett. 40 (1999) 8693.

[13] M. Ihara, A. Katsumata, F. Setsu, Y. Tokunaga, K. Fukumoto, J. Org. Chem. 61 (1996) 677.

[14] S. Olivero, J.-P. Rolland, E. Duñach, Organometallics 17 (1998) 3747 (and references cited therein).

[15] G. Long, M. E. Meek, J. Environ. Sci. Heal. C19 (2001) 161.

[16] J. H. Sohn, M. J. Han, M. Y. Lee, S.-K. Kang, J. S. Yang, J. Pharmaceut. Biomed. 37 (2005) 165.

[17] E. Duñach, A. P. Esteves, M. J. Medeiros, S. Olivero, Green Chem. 8 (2006) 380.

[18] B. Bosnich, M. L. Tobe, G.A. Webb, Inorg. Chem. 4 (1965) 1109.

[19] C. Gosden, K. P. Healy, D. J. Pletcher, Chem. Soc., Dalton Trans. 8 (1978) 972.

[20] E. Duñach, A. P. Esteves, M. J. Medeiros, S. Olivero, New J. Chem. 4 (2005) 633.

[21] S. C. Bobzin, J. D. Faulkner, J. Nat. Prod. 54 (1991) 225.

[22] E. Duñach, A. P. Esteves, A. M. Freitas, M. A. Lemos, M. J. Medeiros, S. Olivero, Pure Appl. Chem. 73 (2001) 1941.

[23] A. P. Esteves, D. M. Goken, J. L. Klein, M. A. Lemos, M. J. Medeiros, D. G. Peters, J. Org. Chem. 68 (2003) 1024.

[24] E. Duñach, A. P. Esteves, M. J. Medeiros, S. Olivero, Tetrahedron Lett. 45 (2004) 7935.

[25] S. Olivero, R. Perriot, E. Duñach, A. R. Baru, E. D. Bell, R. S. Mohan, Synlett 13 (2006) 2021.

[26] S. Derien, E. Duñach, J. Périchon, J. Am. Chem. Soc. 113 (1991) 8447. 